UDK $674.8: 539.3$

DOI: $10.15393 / \mathrm{j} 2$. art.2016.3521

Article

\title{
Debarking waste processing: a systematic review
}

\section{Timmo A. Gavrilov ${ }^{1, *}$, Tatyana B. Stankevich ${ }^{1}$, Olga A. Anpilogova ${ }^{\mathbf{1}}$, Gennady N. Kolesnikov ${ }^{1}$ and Leonid A. Chernyaev ${ }^{1}$}

1 Petrozavodsk State University, Lenin Str. 33, 185910 Petrozavodsk, Russia; E-Mails: gavrilov@petrsu.ru (T.A.G.), gladiolus@list.ru (T.B.S.), anpilogova@petrsu.ru (O.A.A.), kgn@petrsu.ru (G.N.K.), leo@petrsu.ru (L.A.C.)

* Author to whom correspondence should be addressed; E-Mail: gavrilov@petrsu.ru (T.A.G.); Tel.: +7(8142)711046; Fax: +7(8142)711000.

Received: 25 August 2016 / Accepted: 15 October / Published: 30 October 2016

\begin{abstract}
Debarking is an essential part in the technology of round timber processing. A large number of reports have been devoted to the problem of debarking methods and devices improvement. According to some estimation the annual debarking waste makes about 6 mln cubic meters. Taking into consideration these circumstances the importance of the research focused on the rational use of the debarking waste is increasing nowadays. For this reason it is necessary to systematize all known results in this field to clarify the prospects for future research. This article gives a systematic review and analysis of the effectiveness of existing technologies for debarking waste processing. Both the most common debarking processing technologies - export to earth boards and ashing for obtaining thermal and electric power - and promising - anaerobic fermenting and fermentation - are reviewed. Debarking waste should become cost-effective secondary resource instead of a significant problem for wood processing enterprises.
\end{abstract}

Keywords: round timber, debarking, secondary resource, debarking waste, debarking processing technologies 


\section{Introduction}

An essential part in the technology of round timber processing is its debarking. Sliced, mechanical, frictional, hydraulic, chemical methods as well as debarking with ultrasound in water environment and others are used for this purpose [1, 2, 3]. Bark residue got in the result of this operation (according to the GOST R 56070-2014 "Waste Wood Specifications": bark shredding, bast fiber, xylem, peripheral part of the stick of different form and size got in the result of timber debarking) makes $7-15 \%$ of the body wood total volume $[4,5,6]$. Up to 6 million cubic meters of debarking waste are produced at forest industry complex enterprises of Russian Federation annually. On one hand this is a significant problem for timber processing enterprises connected with the need of additional costs for its processing. At the same time, on the other hand it is the most valuable secondary resource. Its rational processing can raise the cost-effectiveness of round timber processing in general and move to the waste-free production. Unfortunately, the current level of industrial debarking waste processing is rather low and that is an important problem. The greatest mass of the debarking waste is transported to the earth boards (50-60\%), a part of it is burned in furnace of steam shops (30-40\%), the rest is used for production of slabby and construction materials, extraneous materials, composts and so on (10-12\%) [4, 5, 7]. The reasons for this are special characteristics of debarking waste (high moisture, extra ash content and a significant content of inorganic impurities), low efficiency and profitability of existing technologies, high cost of the equipment as well as insufficient knowledge of advanced technologies. To solve this problem is possible by examining existing and future technologies for debarking waste processing. And this is the aim of the present work.

\section{Materials and Methods}

The materials and methods used in this study is a systematic review of scientific publications for the period from 2000 to 2016. eLIBRARY.RU, Scopus. Web of Science, AGRIS, EBSCO, VINITY RAS, CYBERLENINKA, Russian State Library, Federal Institute of Industrial Property database have been used. Keywords "debarking waste", "wood waste", "bark" in combination with "processing", "recycling" and "recovering" and some others are used. Priority is given to the scientific publications for the last 5 years and highly quoted sources. Literature lists of received sources have also been reviewed to educe additional relevant ones.

\section{Results}

The most common and simplest technology of debarking waste processing is transporting it to earth boards or burning to get heat and electricity.

Transporting debarking waste to earth boards is the most irrational technology of its processing. This technology includes collecting debarking waste, transporting it to specially equipped earth boards and storing till complete decomposition [4, 5, 6, 7, 8, 9]. Storing debarking waste in earth boards leads to highly undesirable consequences - fires and environmental pollutions. During long 
storage of the debarking waste it partly decomposes and different organic compounds are released. Released products (phenol type compounds) are mostly high toxic for biocoenosis functioning. Dissolved in atmospheric water (rain or snow) decomposition products of debarking waste can weep into ground water and then flow into surface water bodies and contaminate them. Besides forest industry enterprises bear significant costs on transporting debarking waste, maintaining earth boards and renting land for them.

Burning technology of debarking waste for heat and electricity includes grinding it, dehydration (drying) and burning in furnaces [4, 5, 6, 7, 8, 9]. There are a lot of varieties of this technology. The most common is burning in a thin and heavy layer, in suspension, in fluidized and spouted beds. The necessary condition for the functioning of this technology is reducing moisture to 50-60\% of the initial $70-85 \%$. For this, methods of moisture pressing from the debarking waste with co rotating presses and drying it with hot air and smokestack exhaust gases are used. Despite the fact that this technology is widespread and takes the dominant position in industrial use in most cases it is economically inefficient. It is connected with high energy costs for debarking waste dehydration and grinding, often comparable with the amount received in the result of the burning process, as well as with high ash content leading to the formation of coke on the inner surface of furnaces. Besides, debarking waste used as fuel has a high level of burning waste emission in flue gases leading to environmental pollution, and they are characterized by the ability to slog and mat. Thus, debarking waste burning technology to produce heat and electricity is seen as a necessary measure, designed to utilize debarking waste, often with losses for enterprises.

Congenial to the technology of debarking waste burning is the technology of fuel briquettes production [5, 6, 10], which includes debarking waste grinding, drying, dry mass sorting, drying agent production, briquetting, briquettes ageing and their packaging. The advantages of this technology are reduced transport costs and high caloric value of fuel briquettes. But the barrier to the wide use of this technology is also high cost of grinding, drying and briquetting the debarking waste as well as the ability of fuel briquettes swell and disintegrate when exposed to atmospheric moisture.

The alternative to the debarking waste burning technologies and the production of fuel briquettes is the technology of pyrolysis of debarking waste $[5,6,8,11]$. During the pyrolysis process debarking waste heating to a high temperature without air) there occurs pyrogenetic decomposition of complex substances to simpler ones, resulting in formation of solid (charcoal), liquid (acetic acid, methyl alcohol, solvents, resins) and gaseous products. Charcoal is of the greatest interest among the products obtained during the pyrolysis as its activation by steam or carbon dioxide at a high temperature allows to obtain activated charcoal which can be used for purification of wastewater and gas emissions. The wide dissemination of this method is prevented by the high capital and operating costs.

There are other debarking waste use technologies for the purification of industrial emissions and protection the environment from pollution. For example, the technology of using debarking waste kollaktivistov (decolorizing charcoals), which are used as sorbents for purification of sewage [5, 6]. The technology includes debarking waste treatment operations by the use of sulfuric acid at high 
temperatures. Or there is a debarking waste use technology for cleaning the water surface from oil products [5, 6]. Debarking waste, ground to a powder, absorbs oil or black oil from the water, the debarking waste particles, soaked with oil, form clusters that float on the water surface and can be easily removed from it. They can then be used as fuel. The disadvantages of this technology are the high cost of debarking waste grinding and its special treatment which is necessary to prevent leaching extractives, adversely affecting the waters biocoenosis, into the water.

Debarking waste is used in construction. Thus, the technologies of using debarking waste for the production of plate and building materials (wood bark plates WBP, cement carolit, wood plastic composites) have been developed $[4,6,7,8,12,13]$. These technologies and the equipment used are identical to those applied in the production of chipboards. The advantage of plate and construction materials obtained from debarking waste is their low cost, due to the lower cost of raw materials. However, they have lower strength and elasticity than conventional chipboards. This fact does not allow them to compete in the market of plate and building materials.

In agriculture, different technologies of debarking waste processing are used, depending upon the final processed product. Primarily, this is the technique of composting debarking waste to obtain organic or organomineral fertilizers $[4,5,14,15,16,17]$. The technique comprises debarking waste grinding, preparing a mixture with mineral and / or organic additives, using the mixture for further formation of the heaps with air channels, heaps aeration and the decomposition of the mixture to humus. The disadvantages of this method are a long-term processing of 2 to 6 months, strong dependence of the efficiency of this technology on climatic conditions and the season, as well as the need to use large areas.

The technology of debarking waste vermicomposting is similar to that of composting $[5,18,19$, 20, 21], and includes debarking waste shredding, mixing it with manure or droppings of farm animals, heaps laying, putting earthworms or manure worms into them, heaps aeration and the decomposition of the mixture to vermicompost by the worms. The advantage of this technology is that debarking waste processing results in highly effective organic fertilizer - vermicompost, and feed protein - the worm biomass. The disadvantages of this method are also a long-term processing of 2 to 12 months, strong dependence of the efficiency of this technology on climatic conditions and the season, as well as the need to use large areas.

Debarking waste use technology is also applied to meet the needs of agriculture to produce bedding for farm animals and poultry $[5,6,7]$. It includes debarking waste shredding and laying it on the floor of livestock buildings. After using the mixture of shredded debarking waste and manure or droppings is composted. Another technology is a technology of using debarking waste as a mulch material for protecting soil from erosion and weeds [5, 6]. The advantage of mulch debarking waste material is that over time it does not crust, harden or become overgrown with weeds.

No less interesting is the use of debarking waste technology as a source of raw materials for the feeding of farm animals [5, 22]. Debarking waste is converted into nutritious carbohidrate feed with a high content of monosaccharides by means of saccharifications.

Debarking waste is a source of valuable extractives (tannins, wax, alkaloids, carbohydrates, terpenes, resin acids, esters), the obtaining of which is possible only by means of chemical 
processing. In this connection, there are various techniques of chemical debarking waste processing $[5,6,7,8,24]$. Unfortunately, these techniques are not widely used yet, due to the low content of chemical elements in the debarking waste, the complexity of their extraction, competition with synthetic analogues.

There are also less common and more exotic debarking waste use technologies [5, 14, 25, 26, 27 , $28,29,30]$. For example, in the Nordic countries they apply debarking waste use technology as an insulating material in the construction of railways and roads to protect them from freezing [5]. In some forest nurseries of the Russian Federation they apply debarking waste use technology as a substrate component for growing seedlings with closed root system [25]. There is also [14, 26, 27], the technology of anaerobic fermentation of debarking waste transforming it into biogas and biofertilizer, and the technology of aerobic fermentation of debarking waste in fermenters where it is converted into bio-fertilizer.

\section{Discussion and Conclusions}

Each of the debarking waste technologies discussed has both its advantages and disadvantages. At the same time the common for most of them, except for the debarking waste disposal technology, where dumps are used, and the debarking waste burning technology, is that there is no possibility for the processing of debarking waste, formed on the timber processing enterprises on an industrial scale. In this connection, as it has been said earlier these technologies include no more than $10-20 \%$ of the total volume of the processed debarking waste. Undoubtedly, many of the technologies have some prospects in the future, but of course they require complex theoretical and experimental research to improve them in accordance with modern technical possibilities, economic viability and environmental safety.

The final choice of the direction of debarking waste processing can be made only after a thorough technical and economic analysis of the conditions of production and production needs has been done, while debarking waste processing should be comprehensive. Debarking waste being now a significant problem for the timber processing enterprises should become a profitable secondary resource.

\section{Acknowledgments}

The work has been done in the framework of the PetrSU strategic development Program for 2012-2016.

\section{References}

1. Nikonova, Y., Rakovskaya, M., Dospehova, N., Zaitseva, M. 2014. Review of pulpwood debarking processes investigations. Resources and Technology 11 (1): 11-49.

2. Isokangas, A., Leiviskä, K. 2005. Optimization of wood losses in log debarking drum. Paperi ja puu 87 (5): 324-328. 
3. Shegelman, I.R., Vasilyev, A.S. 2016. A brief analysis of the way the group debarking. Innovative technologies in science and education 2 (6): 289-290.

4. Tsivin, M.M. 1973. The use of tree bark. The forest industry, Moscow, Russia, 96 pp.

5. Rudakova, L.V. 1996. Development of technology for utilization of solid waste of pulp and paper production method vermicultivation, Moscow, Russia, $144 \mathrm{pp}$.

6. Pásztory, Z., Mohácsiné, I.R., Gorbacheva, G., Börcsök, Z. 2016. The utilization of tree bark. BioResources $11 \quad$ (3). Available online: https://www.ncsu.edu/bioresources/BioRes_11/BioRes_11_3_7859_REVIEW_Pasztory_MGB Utilization_Tree_Bark 9371.pdf (accessed on 01.08.2016).

7. Feng, S., Cheng, S., Yuan, Z., Leitch, M., Xu, C. 2013. Valorization of bark for chemicals and materials: A review. Renewable and Sustainable Energy Reviews 26: 560-578.

8. Volynsky, V. 2012. Processing and use of wood bark. LesPromInform 2 (84): 168-170.

9. Gavrilov, T.A., Kolesnikov, G.N. 2015. Analysis of debarking waste recycling trends. Actual directions of scientific researches of the XXI century: theory and practice 9-2 (20-2): 115-118. V. 3.

10. Melin, S. 2008. Bark as feedstock for production of wood pellets. Wood Pellet Association of Canada. Available online: http://www.pellet.org/images/2008-12-11 Bark_as_feedstock_for_Production_of_Wood_Pellets_Report_December_2008.pdf (accessed on 01.08.2016).

11. Şensöz, S. 2003. Slow pyrolysis of wood barks from Pinus brutia Ten. and product compositions. BioResources 89 (3): 307-311.

12. Aydin, I., Demirkir, C., Colak, S., Colakoglu, G. 2016. Utilization of bark flours as additive in plywood manufacturing. European Journal of Wood and Wood Products. Available online: http://link.springer.com/article/10.1007\%2Fs00107-016-1096-0 (accessed on 01.08.2016).

13. Safdari, V., Khodadadi, H., Hosseinihashemi, S.K., Ganjian, E. 2011. The effects of poplar bark and wood content on the mechanical properties of wood-polypropylene composites. BioResources 6 (4): 5180-5192.

14. Golubev, I.G. Svenska, I.A., Konovalenko, L.Yu., Lopatnikov M.V. 2011. Waste recycling in agriculture: a Handbook. FGNU «Rosinformagrotech», Moscow, Russia, 296 pp.

15. Vandecasteele, B., Willekens, K., Zwertvaegher, A., Degrande, L., Tack, F. M. G., Du Laing, G. 2013. Effect of composting on the $\mathrm{Cd}, \mathrm{Zn}$ and $\mathrm{Mn}$ content and fractionation in feedstock mixtures with wood chips from a shortrotation coppice and bark. Waste Management 33 (11): 2195-2203.

16. Vandecasteele, B., Reubens, B., Willekens, K., De Neve, S. 2014. Composting for Increasing the Fertilizer Value of Chicken Manure: Effects of Feedstock on P Availability. Waste Biomass 5: 491-503.

17. Devyatovsky, A.N., Zhuravleva, L.N., Deviatovski, N.I. 2010. Utilization of wood bark wood processing enterprises. Actual problems of forestry complex 27: 51-54. 
18. Gavrilov, T.A., Patalaynen, L.S., Kolesnikov G.N. 2014. About resourcesaving technology of ecologically safe utilization of tree bark. Modern scientific researches and innovations 7 (39): $59-64$.

19. Gavrilov, T.A. 2014. Waste recycling resource conserving technologies in the form of wood biomass. Resource-saving technologies, materials and structures: proceedings of the regional scientific-practical conference. Petropress, Petrozavodsk, Russia, 20-24 pp.

20. Huang, K. 2013. Changes of bacterial and fungal community compositions during vermicomposting of vegetable wastes by Eisenia foetida. Bioresource Technology. Available online: http://www.sciencedirect.com/science/article/pii/S0960852410016226 (accessed on 01.08.2016).

21. Kumar, R. 2011. Enhancement of wood waste decomposition by microbial inoculation prior to vermicomposting. Bioresource Technology. Available online: http://www.sciencedirect.com/science/article/pii/S0960852410016226 $\quad$ (accessed on 01.08.2016).

22. Filichkina, M.V., Sushkov, A.S. 2013. Rational use of wood waste. Voronezh scientific and technical Bulletin 4 (6): 27-31.

23. Dedriea, M., Jacquetb, N., Bombecka, P.-L., Héberta, J., Richel, A. 2015. Oak barks as raw materials for the extraction of polyphenols for the chemical and pharmaceutical sectors: A regional case study. Industrial Crops and Products 70: 316-321.

24. Garcia, D.E., Glasser, W.G., Pizzi, A., Paczkowski, S., Laborie, M.P. 2015. Hydroxypropyl tannin from Pinus pinaster bark as polyol source in urethane chemistry. European Polymer Journal 67: 152-165.

25. Burchak, V.I. Zaitseva, M.I., Gorbacheva, N.A. 2014. Utilization of waste wood preparation cycle pulp and paper mill. Wooden low-rise housing: Economics, architecture and resourcesaving technologies: a collection of articles of scientific-practical conference. Petropress, Petrozavodsk, Russia, 40-44 pp.

26. Kovalev, N.G., Polozov, V.G., Baranovsky, E.N. 2009. Organic raw material utilization into fertilizer by bioconversion method. Machinery and Equipment for Rural Area 1: 25-27.

27. Yang, L., Xu, F., Ge, X., Li, Y. 2015. Challenges and strategies for solid-state anaerobic digestion of lignocellulosic biomass. Renewable and Sustainable Energy Reviews 44: 824-834.

28. Gerasimov, Y., Karvinen, S., Syunev, V., Sokolov, A., Katarov, V. 2009. Development of wood transport infrastructure - Finnish experience. Transport business of Russia 7: 99-102.

29. Seliverstov, A.A., Gerasimov, Yu.Yu., Sukhanov, Yu.V., Syuniov, V.S., Katarov, V.K. Evaluation of effectiveness of the wood chips production in timber terminal. Tractors and agricultural machinery 8: 25-27.

30. Gerasimov, Y., Seliverstov, A., Syunev, V. Industrial round-wood damage and operational efficiency losses associated with the maintenance of a single-grip harvester head model: a case study in Russia. Forests 4 (3): 864-880.

(C) 2016 Gavrilov T. A., Stankevich T. B., Anpilogova O. A., Kolesnikov G. N., Chernyaev L. A. 